\title{
A Modified High Voltage Gain SEPIC Based DC-DC Converter with Continuous Conduction Mode
}

\author{
G.Vijaykumar ${ }^{1} \mid$ Dr.V.Geetha ${ }^{2}$
}

${ }^{1}$ Research scholar, Department of Electrical and Electronics Engineering, Government College of Engineering, Salem, Tamilnadu, India

${ }^{2}$ Professor, Department of Electrical and Electronics Engineering, Government College of Engineering, Salem, Tamilnadu, India

\section{To Cite this Article}

G.Vijaykumar and Dr.V.Geetha, "A Modified High Voltage Gain SEPIC Based DC-DC Converter with Continuous Conduction Mode", International Journal for Modern Trends in Science and Technology, 6(12): 268-274, 2020.

\section{Article Info}

Received on 10-November-2020, Revised on 02-December-2020, Accepted on 06-December-2020, Published on 11-December-2020.

\section{ABSTRACT}

A high voltage gain modified SEPIC converter is proposed in this paper. This proposed converter has many advantages i.e., high output voltage, lower voltage stress, high efficiency, voltage gain is high without any coupled inductor and transformer, continuous input current. Thus, there is no overshoot voltage at turn-off process for switches. By using single switches, the CCM mode operation can be easily controlled by this converter, so control system is simple and also wide output values is obtained only by modifying the duty cycle. This modified converter has lower components than conventional converter. The operating modes and design of modified converter are discussed. The output power of this converter is 6 watts. By this converter, this converter capable of developing the two and half times of input voltage. The PV system also used this converter to develop high voltage gain. This high voltage gain is achieved by using MATLAB/SIMULIMK platform.

KEYWORDS: DC-DC converter, non-isolated converter, non-coupled inductor SEPIC converter, High step up SEPIC converter.

\section{INTRODUCTION}

In recent years, improved voltage gain is an important research area. Due to increasing in demand of high voltage gain converters for various applications, this converter is proposed. DC to DC converters are widely used in power electronic appliances, industry field and renewable energy applications. Low power wind turbine, PV, fuel-cells, embedded systems, portable electronic equipment's, uninterruptable power supply (UPS), electric tractions, battery backup for UPS, automobile headlamps, some medical equipment and battery powered equipment are some applications of improved gain DC-DC converters [1]. In this converter, the input current is continuous. By this converter, the ripple and voltage stress on switches are reduced with high voltage gain. The boost converter is used to step up the output voltage. In order to boost the output voltage, continuous input current is preferred more than discontinuous input current due to some disadvantages [2]. Boost converter (DC-DC) is used widely to step up the output voltage. But the voltage stress is higher in boost converter and also high rated switch is needed. And also, traditional buck-boost converter is used to step up or step down the voltage level. But it is not suitable for high voltage gain by the discontinuous input current. Several dc-dc converters such as the fly-back converter, single-ended primary-inductance converter (SEPIC), the Cuk converter, forward converter, inverting buck-boost 
converter has been proposed to obtain the high voltage gain and high efficiency. In fly-back converter, efficiency is low due to its high-leakage inductance and transformer is required. The high gain buck-boost converter without transformer has discontinuous input current and negative polarity so it is not suitable.

Mostly isolated DC-DC converters used in high voltage gain. In isolated $\mathrm{DC}-\mathrm{DC}$ converters, the overall weight and volume is increased by transformer and also high voltage gain is achieved by transformer turns ratio. During turn off process, the transformer causes voltage spikes due to leakage inductance. The switch voltage is limited by additional clamping circuits and also it recycles the energy. Due to this, cost and complexity is increased with reduced efficiency [3].

Nowadays, a non-isolated dc-dc converter is used widely because of its simplicity, small size, and high efficiency, low cost in comparison with other converters [4].

Due to unique characteristics of SEPIC converter, it is most widely used in power electronics and other applications. In several papers, high voltage gain SEPIC converter is achieved with transformer and coupled inductor but due to its aforementioned drawbacks, it is not widely used [10]-[12]. To improve the performance of SEPIC converter, a modified high voltage gain SEPIC converter is presented in this paper. The proposed converter is uncomplicated and lower number of components to have gain compared with other converters. In CCM mode of operation, the converter control is easy and simple by using single switches. No clamping circuit is needed.

In this existed converter, $\mathrm{C}_{4}$ charged by secondary side of coupled inductor. In existed converter, the $\mathrm{C}_{3}$ and $\mathrm{C}_{4}$ is charged by both sides of coupled inductor. The voltage across the main switch is clamped by $\mathrm{D}_{1}$ and $\mathrm{C}_{1}$. The existed circuit diagram is shown in the fig. 1 (a). It includes that all capacitors are enough capacity without any ripples in their voltages and also all inductors $\mathrm{L}$ and $\mathrm{L}_{\mathrm{m}}$ are large without any ripples in their currents. All components are ideal. The operation of the existed circuit is in continuous conduction mode (CCM) and it has five intervals. The principle operation of the proposed converter under steady state is explained in two modes. The proposed converter is simple with continuous input current. So, it is suitable for renewable energy applications. The proposed SEPIC DC-DC converter is analysed and performance are verified by the simulation results for low input voltage and high output voltage.

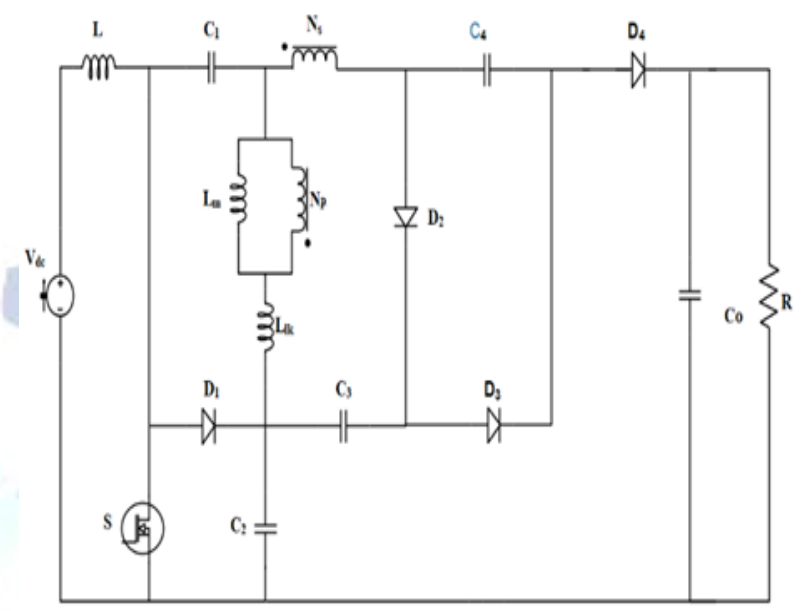

Fig-1(a): Circuit diagram of coupled inductor SEPIC converter.

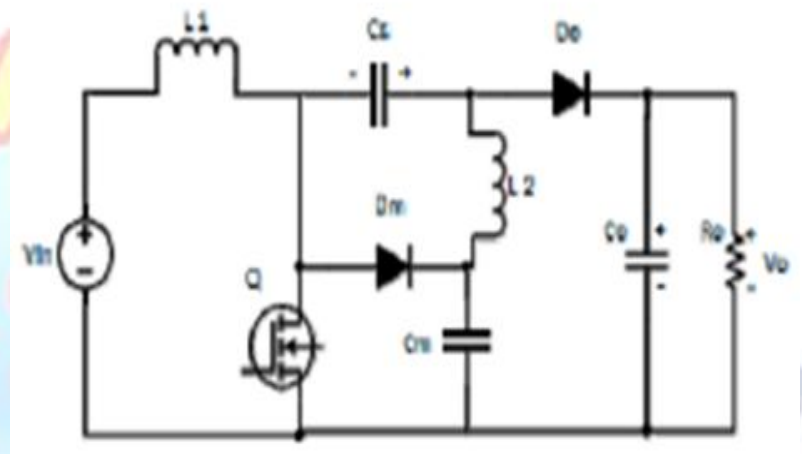

Fig -1(b): Circuit diagram of existing SEPIC converter

Topology of existed converter is modification from conventional SEPIC converter topology which consists of several components, such as inductor $\mathrm{L}_{1}$, inductor $\mathrm{L}_{2}$, capacitor $\mathrm{Cs}$, capacitor $\mathrm{Cm}$, switching device $\mathrm{Q}$, diode $\mathrm{D}_{\mathrm{m}}$, diode $\mathrm{D}_{\mathrm{o}}$ and capacitor $\mathrm{C}_{\mathrm{o}}$. The circuit diagram of existed SEPIC converter is shown in fig. $1(\mathrm{~b})$.

In section II, modes of operation of the proposed SEPIC converter is presented. In section III, comparison with other converters is discussed. In section IV, the experimental results are given, finally, section $\mathrm{V}$, conclusion is presented.

\section{OPERATING PRINCIPLE OF PROPOSED SEPIC CONVERTER}

A modified high voltage gain SEPIC converter is shown in Fig.2. The proposed circuit diagram consisting of single switch (S), inductors $\left(\mathrm{L}_{1}, \mathrm{~L}_{2}, \mathrm{~L}_{3}\right)$, capacitors $\left(\mathrm{C}_{1}, \mathrm{C}_{2}, \mathrm{C}_{\mathrm{o}}\right)$, diodes $\left(\mathrm{D}_{1}\right)$. Three diodes, and two capacitors are reduced from voltage 
multiplier of basic circuit. It has low ripple factor due to utilizing capacitors, inductors. It improves filtering action. The pulsating DC output voltage is filtered by capacitor connected at the output side. The aim of a circuit is to provide ripple free DC output voltage.The operation is divided into two levels depend on time interval.

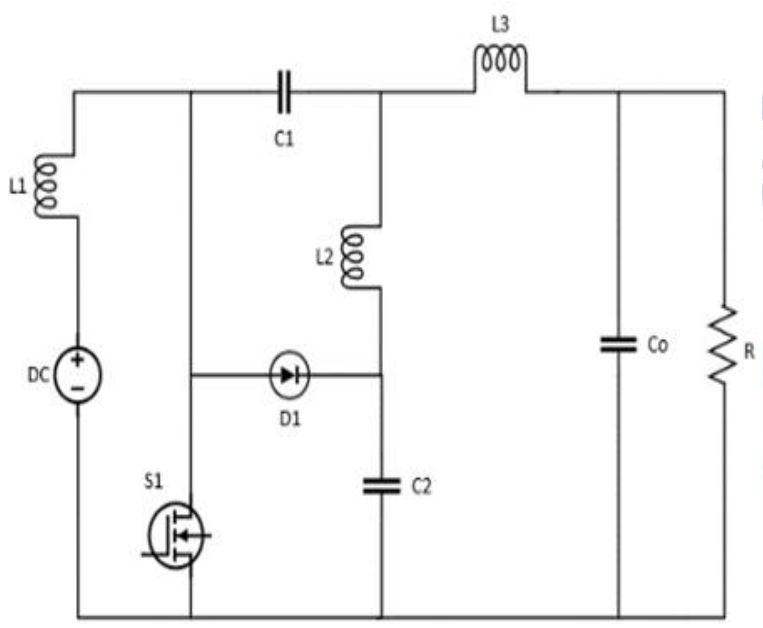

Fig-2: Proposed high step up gain SEPIC converter.

Mode 1: In this mode, switch gets turned on and diode is in reverse conduction. The inductor $\mathrm{L}_{1}$ is charged directly by dc source. The inductor L2 is charged by $\mathrm{C}_{1}$ and the remaining source delivered to $\mathrm{C}_{2}$. The inductor $\mathrm{L}_{3}$ is charged by $\mathrm{C}_{1}$ and $\mathrm{C}_{2}$. The current flow in mode 1 is given in Fig.2(a). From switch on mode,

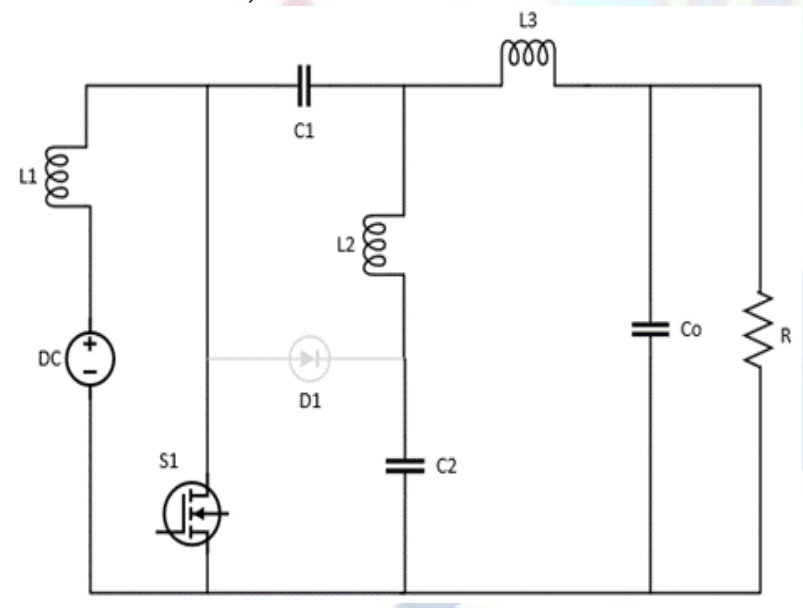

Fig -2(a): Circuit diagram of switch on mode

The voltage across inductors are obtained as,

$$
\begin{aligned}
& V_{L 1}=V_{S} \\
& V_{L 2}=V_{c 1}-V_{c 2}(2) \\
& V_{L 3}=V_{c 2}-V_{0}(3)
\end{aligned}
$$

Mode 2: In this mode, switch gets turned off and diode is in forward conduction. Here also inductor $\mathrm{L}_{1}$ is charged by dc source. The current flow in mode 2 is given in Fig.2(b). Therefore voltage across input inductors are obtained as

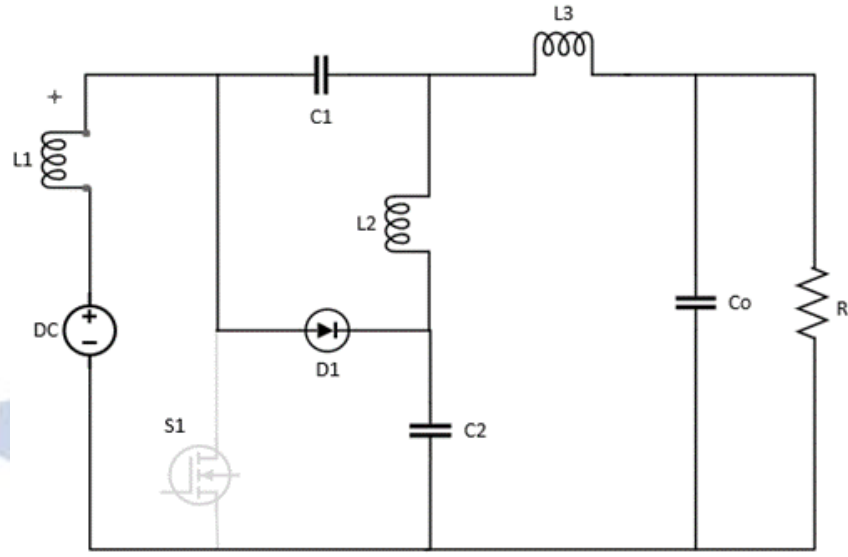

Fig -2(b): Circuit diagram of switch off mode

$V_{L 1}=V s-V_{C 2}(4)$

$V_{L 2}=V_{C 1}(5)$

The voltage across L3 is obtained as

$V_{L 3}=V_{c 2}-V_{0}$

$V_{C o}=V_{0}$

For inductor $\mathrm{L}_{1}$

$$
\begin{aligned}
& \left(V_{C 1}-V_{c 2}\right) *(D T)+\left(V_{c 1}\right) *(T-D T)=0 \\
& V s T-V_{c 2} T+V_{c 2} D T=0
\end{aligned}
$$

$V_{c 2}=\frac{V s}{1-D}(9)$

For inductor $\mathrm{L}_{2}$,

$$
V s * D T+\left(V s-V_{c 2}\right) *(T-D T)=0(10)
$$

Substituting (9) equation in (10),

$$
\begin{gathered}
V_{C 2} D T=V_{C 1} T \\
V_{c 1}=\frac{V s * D}{1-D}(11)
\end{gathered}
$$

For inductor $\mathrm{L}_{3}$,

$\left(V_{C 2}-V o\right) * D T+\left(V_{C 2}-V o\right) *(1-D)=0(12)$

Substituting (9) equation in (12),

$$
V_{C 2}=V o
$$

$V o=\frac{V s}{1-D}$

The voltage gain of the modified SEPIC converter is given by the equation,

$$
\frac{V_{O}}{V_{\text {in }}}=\frac{1}{1-D}
$$

Where,

$\mathrm{D}$ is the duty ratio of switching pulse 
$\mathrm{V}_{\mathrm{C} 1}$ is the capacitor voltage across capacitor $\mathrm{C}_{1}$

$\mathrm{V}_{\mathrm{C} 2}$ is the capacitor voltage across capacitor $\mathrm{C}_{2}$

$\mathrm{V}_{\mathrm{L} 1}$ is the inductor voltage across inductor $\mathrm{L}_{1}$

$\mathrm{V}_{\mathrm{L} 2}$ is the inductor voltage across inductor $\mathrm{L}_{2}$

$\mathrm{V}_{\mathrm{o}}$ is the output voltage

$\mathrm{V}_{\mathrm{S}}$ is the input voltage.

The voltage gain $\left(\mathrm{V}_{\mathrm{o}} / \mathrm{V}_{\mathrm{in}}\right)$ is necessary for duty cycle ratios.

\section{COMPARISON WITH OTHER CONVERTERS}

The proposed converter features are comparing with other converter topologies like conventional SEPIC converter, boost converter is provided in table I. The table shows the voltage gain is high in proposed converter than the classical SEPIC converters and it is gain same for boost converter. In table I, the voltage stress on switches in proposed converter is low. The number of components is high compared with existed converter. The proposed converter shows continuous input current as same as conventional SEPIC converter. The high voltage gain is achieved by using single switches, one diode, three inductors and three capacitors.

Table-1: Comparison between the proposed converter and other converters

\begin{tabular}{|c|c|c|c|c|}
\hline Parameters & Propos & Existi & SEPI & Boo \\
\hline Voltage gain & $\frac{1}{1-\mathrm{D}}$ & $\frac{1+D}{1-\mathrm{D}}$ & $\frac{\mathrm{D}}{1-\mathrm{D}}$ & $\frac{1}{1-\mathrm{D}}$ \\
\hline $\begin{array}{c}\text { Number of } \\
\text { switches }\end{array}$ & 1 & 1 & 1 & 1 \\
\hline $\begin{array}{c}\text { Number of } \\
\text { diodes }\end{array}$ & 1 & 2 & 1 & 1 \\
\hline $\begin{array}{c}\text { Number of } \\
\text { inductors }\end{array}$ & 3 & 2 & 2 & 1 \\
\hline $\begin{array}{c}\text { Number of } \\
\text { capacitors }\end{array}$ & 3 & 3 & 2 & 1 \\
\hline $\begin{array}{c}\text { Total device } \\
\text { count }\end{array}$ & 8 & 8 & 6 & 4 \\
\hline $\begin{array}{c}\text { Continuous } \\
\text { input current }\end{array}$ & Yes & Yes & Yes & $\begin{array}{c}\text { Yes is } \\
\text { priv } \\
\text { pro }\end{array}$ \\
\hline
\end{tabular}

\section{SIMULATION RESULTS}

The components are specification in table II. The pulse generator is used to generate pulse for switches of converter. The switching frequency in continuous conduction mode is $8 \mathrm{kHz}$ with $60 \%$ duty cycle. This converter based on SEPIC converter. To validate the theoretical analysis of this step-up converter and justify the feasibility of the proposed converter, the experimental results of implemented circuit of the proposed converter are analysed in this session. The simulation diagram for proposed system is shown in Fig.3. This simulation of this converter has been carried out in MATLAB/SIMULINK environment. The connections are made as per the circuit diagram without feedback. An input voltage of $10 \mathrm{~V}$ DC is given to the circuit, with the duty cycle ratio of 60 i.e. $(\mathrm{D}=0.6)$. An output voltage of $24.1 \mathrm{~V} \mathrm{DC}$ and output current is $0.2 \mathrm{~A}$ is obtained. Under the balanced condition, the proposed converter operating in CCM which is caused low current ripples and low stress. Finally, the derived voltage gain equation is similar to the boost converter. The output voltage is improved with duty cycle increases. Here, the voltage is boosted as the operation mainly depends on the duty cycle. The proposed converter is applicable for renewable energy applications because it has continuous input current.

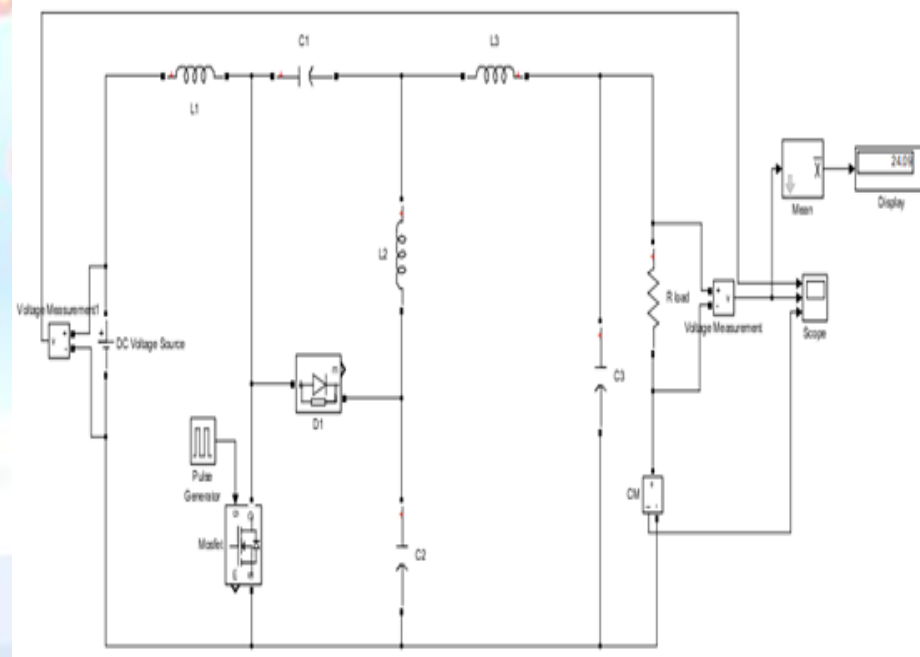

Fig -3: Simulation diagram of the proposed system

The inductor's voltage and current are shown in Fig. 5. The voltage and current of capacitors are given in Fig.6. The pulse generator pulse waveform is given in Fig.4(a). The simulation results of proposed SEPIC converter shows the higher output voltage than other converters.

Table-2: Circuit parameters

\begin{tabular}{|l|c|c|}
\hline Parameter's Name & Symbol & Range \\
\hline Input voltage & $\mathrm{V}_{\mathrm{s}}$ & $10 \mathrm{~V}$ \\
\hline Output voltage & $\mathrm{V}_{\mathrm{o}}$ & $24.1 \mathrm{~V}$ \\
\hline & $\mathrm{L}_{1}$ & $210 \mu \mathrm{H}$ \\
Inductor & $\mathrm{L}_{2}$ & $10 \mathrm{mH}$ \\
\hline
\end{tabular}




\begin{tabular}{|c|c|l|}
\hline & $\mathrm{L}_{3}$ & $1 \mathrm{mH}$ \\
\hline & $\mathrm{C}_{1}$ & $1 \mu \mathrm{F}$ \\
& $\mathrm{C}_{2}$ & $330 \mu \mathrm{F}$ \\
& $2 \mathrm{mF}$
\end{tabular}

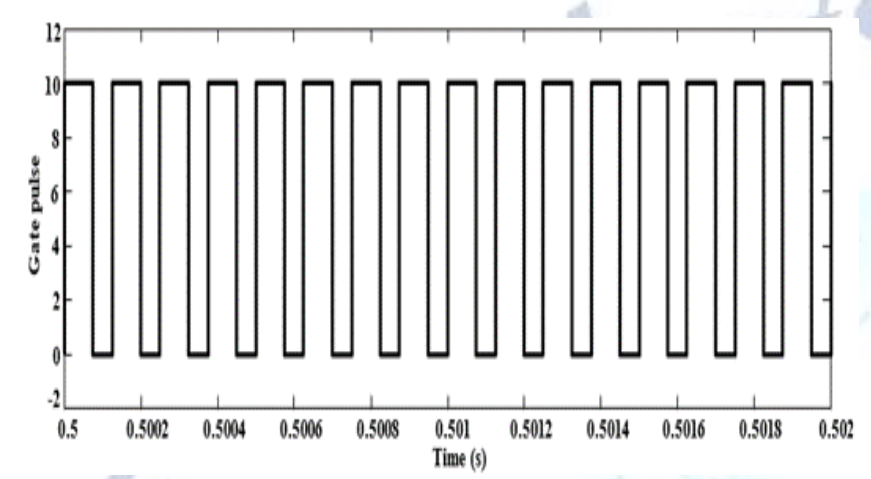

Fig -4(a): Gating pulse to MOSFET switch

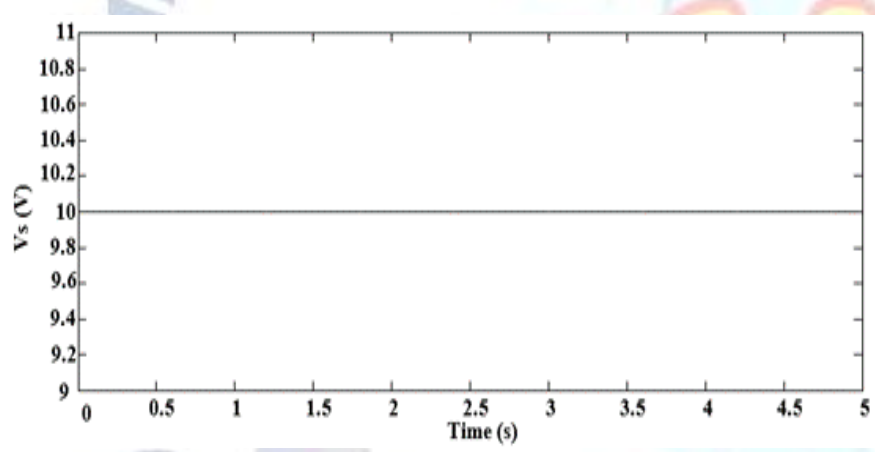

Fig -4(b): Waveform of input voltage (Vs)

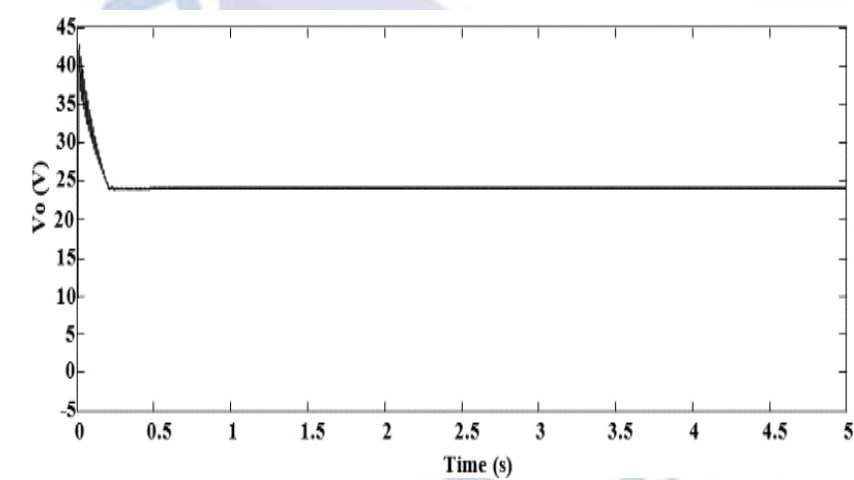

Fig -4(c): Waveform of output voltage (Vo)

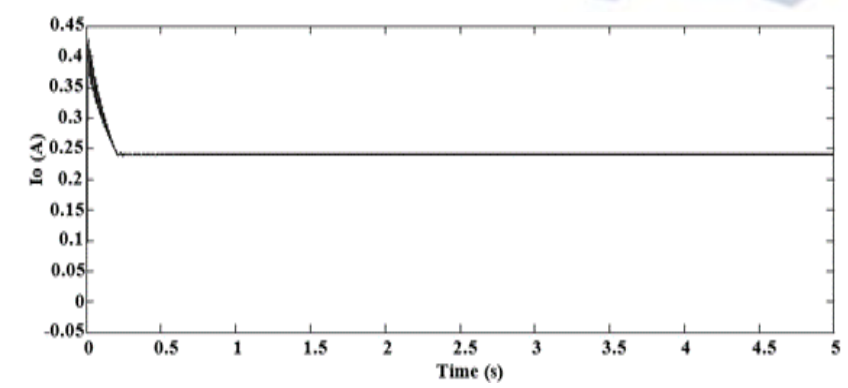

Fig -4(d): Waveform of output current (Io)

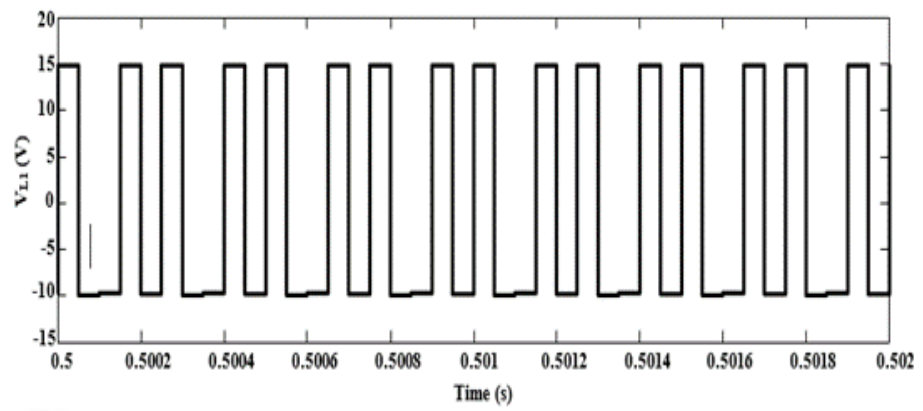

Fig -5(a): Waveform of voltage across inductor $\left(L_{1}\right)$

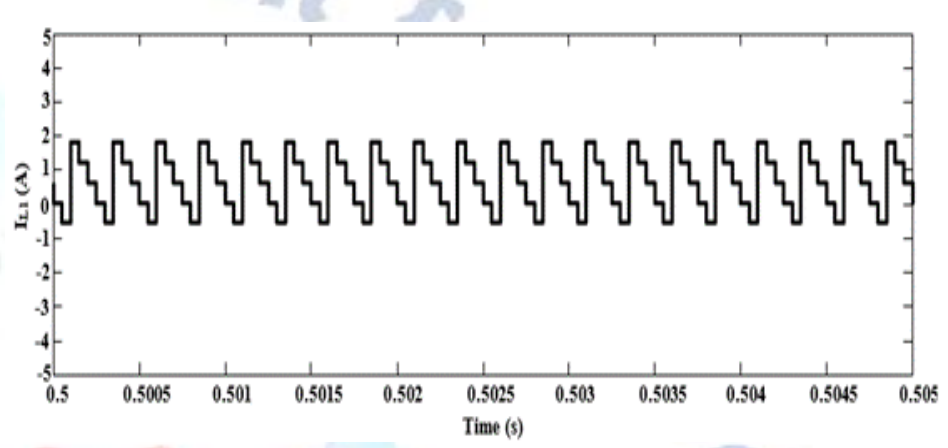

Fig -5(b): Waveform of current through inductor $\left(L_{1}\right)$

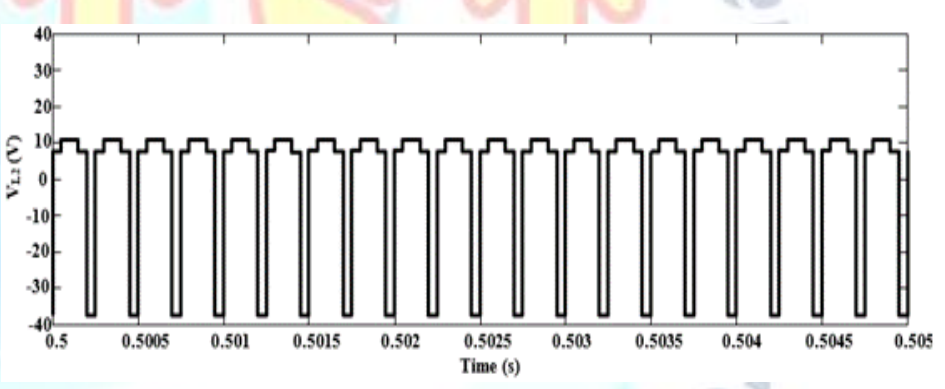

Fig -5(c): Waveform of voltage across inductor (L2)

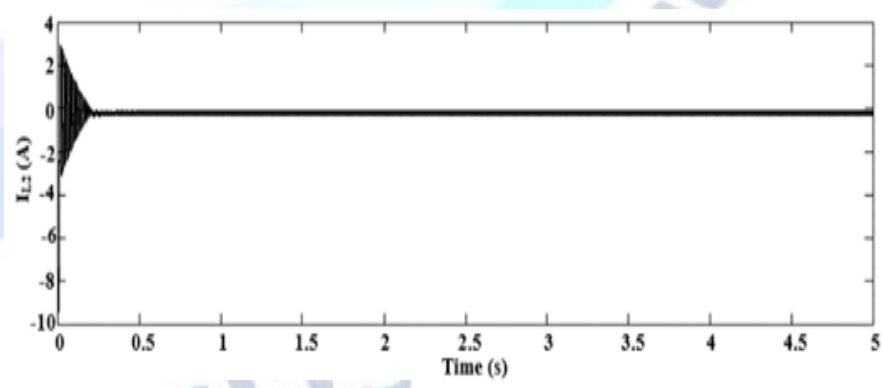

Fig -5(d): Waveform of current through inductor $\left(L_{2}\right)$

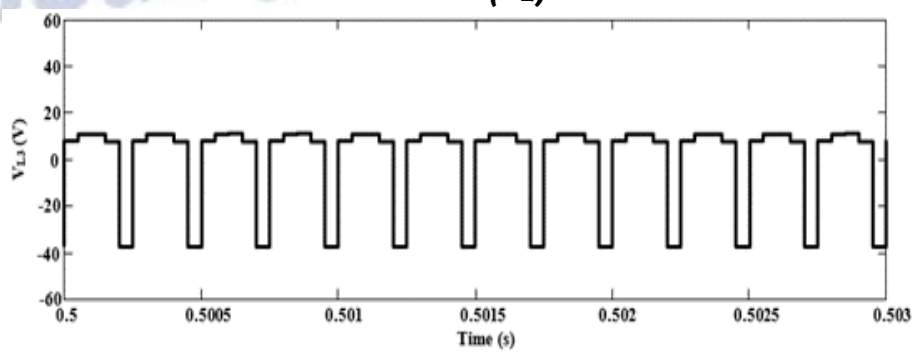

Fig -5(e): Waveform of voltage across inductor 
( $\left.L_{3}\right)$

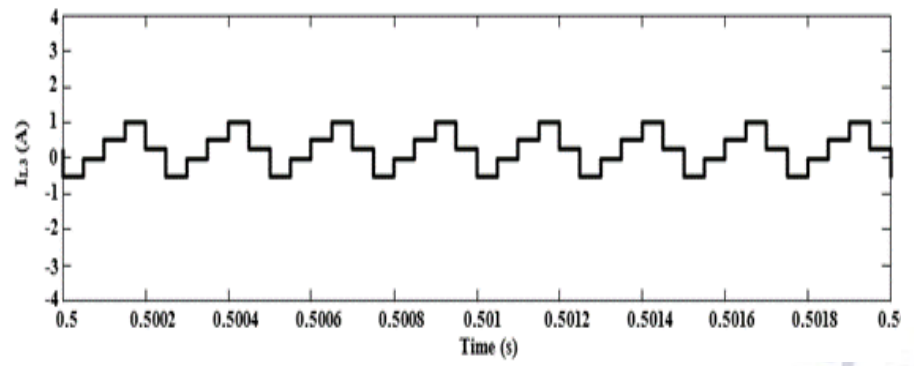

Fig -5(f): Waveform of current through inductor $\left(L_{3}\right)$

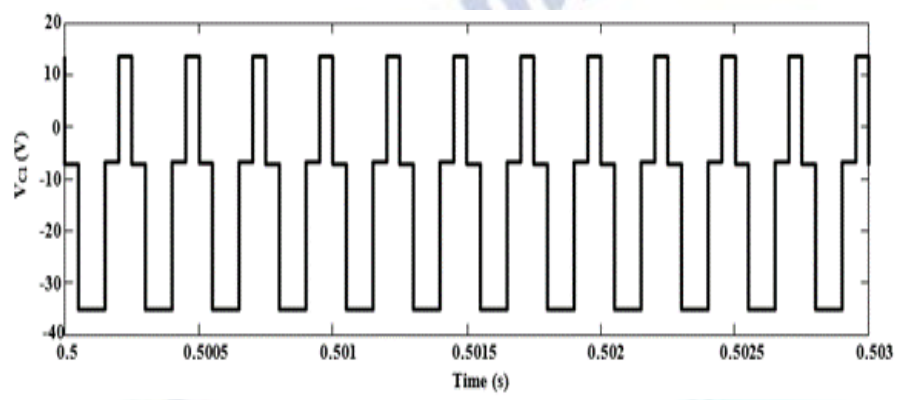

Fig -6(a): Waveform of voltage across capacitor (C)

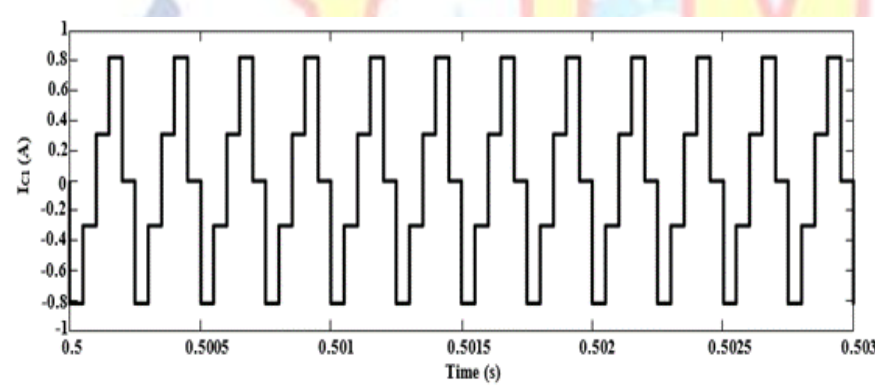

Fig-6(b): Waveform of current through capacitor $\left(\boldsymbol{C}_{1}\right)$

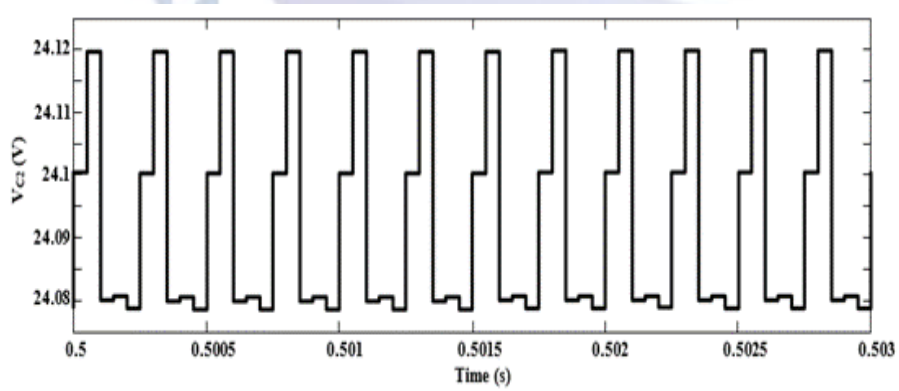

Fig -6(c): Waveform of voltage across capacitor

( $\left.\boldsymbol{C}_{2}\right)$

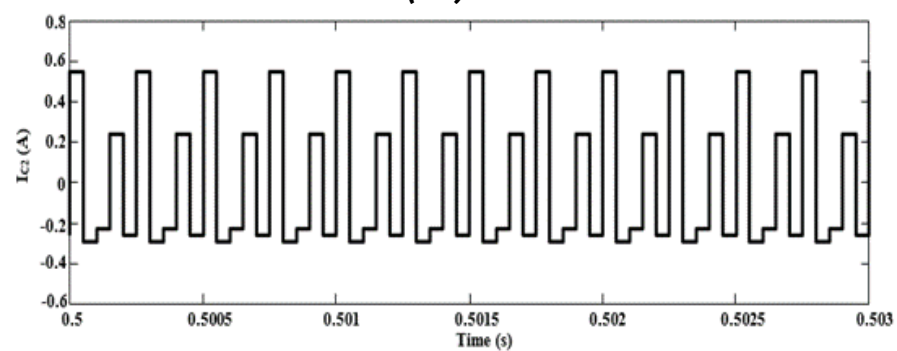

Fig -6(d): Waveform of current through capacitor $\left(\mathrm{C}_{2}\right)$

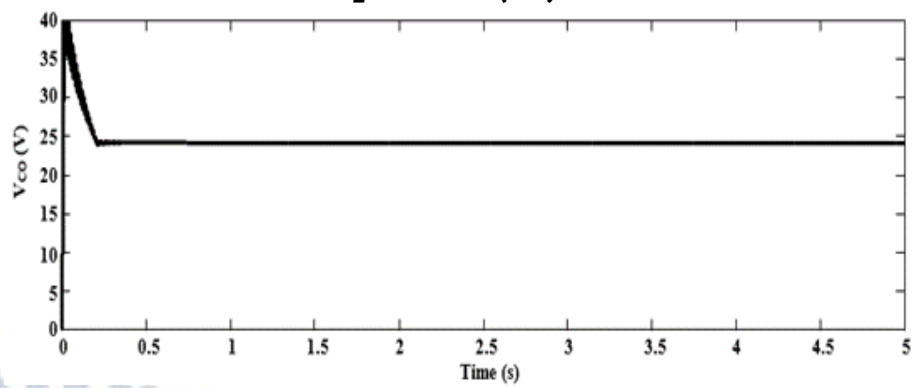

Fig -6(e): Waveform of voltage across capacitor ( $\left.\boldsymbol{C}_{\mathrm{o}}\right)$

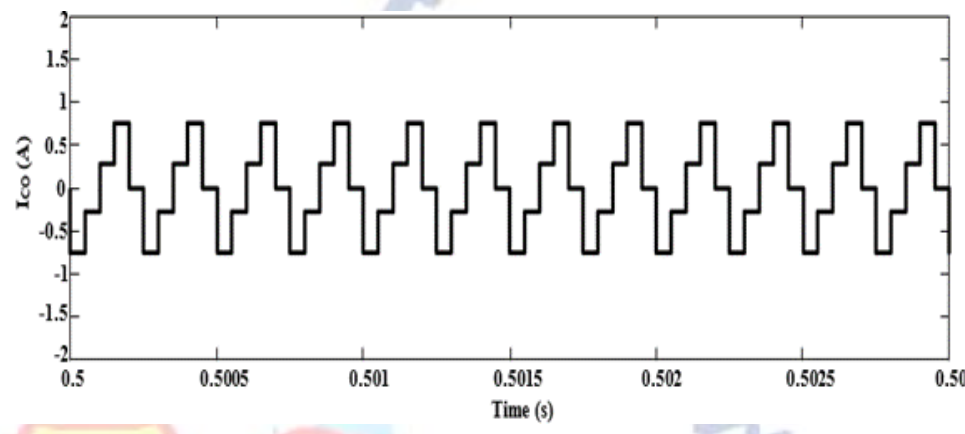

Fig -6(f): Waveform of current through capacitor $\left(\boldsymbol{C}_{\mathrm{o}}\right)$

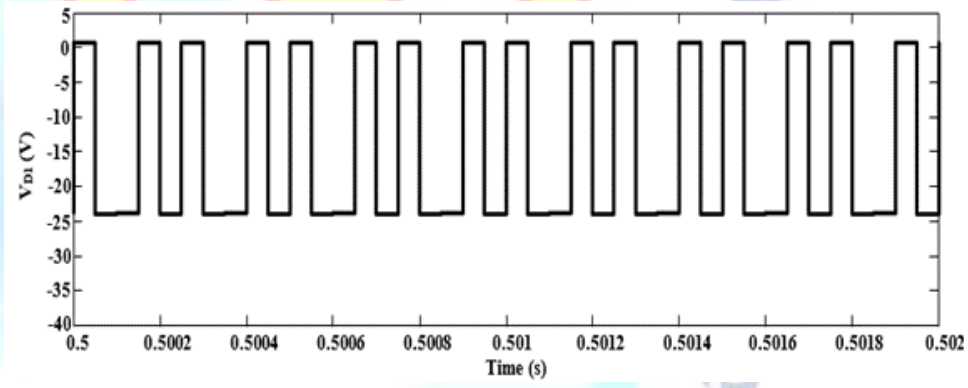

Fig -7(a): Waveform of voltage across Diode $\left(D_{1}\right)$

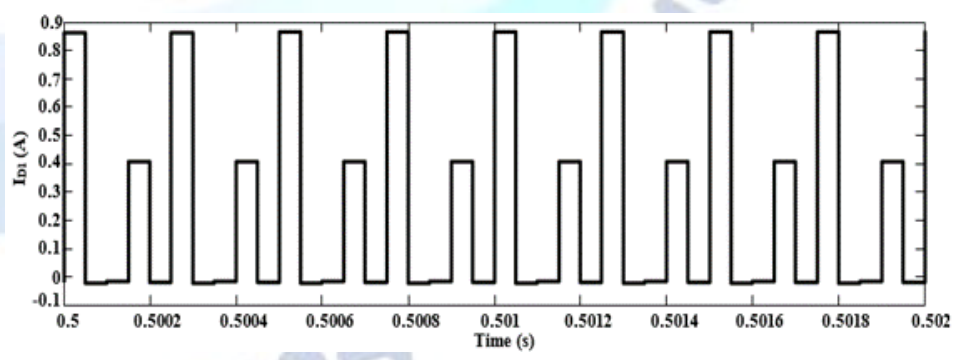

Fig -7(b): Waveform of current through Diode

(D)

\section{CONCLUSION}

A modified high voltage gain SEPIC converter is proposed in this paper. The proposed converter is modified and makes simple. The modified SEPIC converter is tested with an input voltage of $10 \mathrm{~V}$ at a switching frequency of $8 \mathrm{kHz}$. The proposed converter produces desired output voltage $24.1 \mathrm{~V}$. The presented converter has many advantages i.e., 
lower voltage stress, high efficiency, voltage gain is high without any coupled inductor and transformer, continuous input current. The analysis of proposed converter under continuous conduction mode operation have been analysed by MATLAB/SIMULINK platform. Based on the results, the output voltage is higher than the conventional SEPIC converters. To validate the advantages of proposed SEPIC converter, the simulation results were presented.

\section{REFERENCES}

[1] HosseinArdi and Ali Ajami,"Study on A High Voltage Gain SEPIC Based DC-DC Converter with Continuous Input Current for Sustainable Energy Applications", IEEE TRANSACTIONS ON INDUSTRIAL ELECTRONICS, 2018.

[2] H. Suryoatmojo, I. Dilianto, Suwito, R. Mardiyanto, E. Setijadi and D.C. Riawan," Design and Analysis of High Gain Modified SEPIC Converter for Photovoltaic Applications", IEEE International Conference on Innovative Research and Development (ICIRD), 11-12 May 2018.

[3] MahmoodrezaEskandarpourAzizkandi, FarzadSedaghati, HosseinShayeghi , MortezaDezhbord, "A Single-Switch High Step-Up DC-DC Converter Based on Integrating Coupled Inductor and Voltage Multiplier Cell for Renewable Energy Applications", International Power Electronics, Drive Systems and Technologies Conference (PEDSTC), pp. 12-14, February 2019.

[4] H. C. Shu, "Design and analysis of a switched capacitor-based step- up dc/dc converter with continuous input current," IEEE Trans. Circuits Syst.I, Fundam. Theory Appl., vol. 46, no. 6, pp. 722-730, Jun. 1999.

[5] Kshemada Devi V, Anooja V.S, "A Closed Loop Model of Modified SEPIC Converter with Magnetic Coupling and Output Diode Voltage Clamping", International Journal of Advanced Research in Electrical, Electronics and Instrumentation Engineering, Vol. 4, Issue 9, September 2015.

[6] Reza Moradpour, HosseinArdi and AbdolrezaTavakoli, "Design and Implementation of a New SEPIC-Based High Step-Up DC/DC Converter for Renewable Energy Applications", IEEE TRANSACTIONS ON INDUSTRIAL ELECTRONICS, jun. 2017.

[7] D. Meneses, F. Blaabjerg, O. Garcia and J. A. Cobos, "Review and Comparison of Step-Up Transformer less Topologies for Photovoltaic AC Module Application", IEEE Transactions on Power Electronics, vol. 28, no. 6,pp. 2649- 2663, June 2013.

[8] Sara Hasanpour, Alfred Baghramian and HamedMojallali, "A MODIFIED SEPIC-Based High Step-Up DC-DC Converter with Quasi-Resonant Operation for Renewable Energy Applications", IEEE TRANSACTIONS ON INDUSTRIAL ELECTRONICS, 2018.

[9] L.-S. Yang, T.-J. Liang and J.-F. Chen, "Transformer less DC-DC Converters with High Step-Up Voltage Gain", IEEE Transaction on Industrial Electronics, vol. 56, no.8, pp. 3144-3152, August 2009.

[10] Y. P. Hsieh, J. F. Chen, T. J. Liang, and L. S. Yang, "Novel high step-up DC-DC converter with coupled-inductor and switched capacitor techniques," IEEE Trans.Ind.Electron., vol. 59, no. 2, pp. 998-1007,Feb. 2012.

[11] M. Prudente, L. L. Pfitscher, G. Emmendoerfer, E. F.Romaneli and R. Gules, "Voltage Multiplier Cells
Applied to Non-Isolated DC-DC Converters",IEEE Transactions on Power Electronics, vol. 23, no 2, pp. 871887, March 2008.

[12] R. J. Wai, C. Y. Lin, R. Y. Duan, and Y. R. Chang, "High-Efficiency DC-DC converter with high voltage gain and reduced switch stress," IEEE Trans. Ind.Electron., vol. 54, no. 1, pp. 354-364, Feb. 2007.

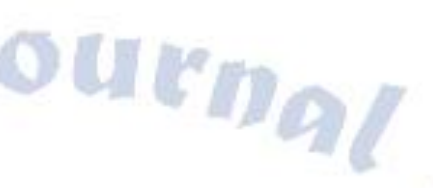

